Artículo original

\title{
Analysis of coexistence and mutual interference between mobile and digital television systems
}

Análisis sobre coexistencia e interferencia mutua entre los sistemas móviles y la televisión digital

Alessandro Guidotti, M.Sc. a.guidotti@unibo.it

Marina Barbiroli, Ph.D. marina.barbiroli@unibo.it

DEIS, University of Bologna (Italy)

Paolo Grazioso, Ph.D. pgrazioso@fub.it

Claudia Carciofi, Ph.D. ccarciofi@fub.it

Doriana Guiducci, Ph.D. dguiducci@fub.it

Guido Riva griva@fub.it

Fondazione Ugo Bordoni Pontecchio Marconi (Italy)

Fecha de recepción: Octubre 6 de 2011 Fecha de aceptación: Noviembre 30 de 2011

Palabras clave

Co-channel interference, Digital

Dividend, UHF band, DVB-T,

LTE

Keywords

Interferencia co-canal, Dividendo digital, banda UHF, DVB-T, LTE

Colciencias 1 tipo

\section{Abstract}

The ever increasing demand for multimedia wireless communication systems is a key feature of more advanced markets. The buzzwords of personal communications, meant to provide "access to anyone, anywhere, at anytime to the wanted service", implies that radio spectrum demands are dramatically increasing in most developed markets. The last World Radiocommunication Conference (WRC-07) allocated on a co-primary basis the upper part of the UHF band to mobile services as from 2015 in Region 1, taking advantage of the Digital Dividend due to the higher spectrum efficiency of digital TV with respect to the analogue system. This will cause potentially harmful mutual interference between $\mathrm{TV}$ and mobile radio services, that needs to be carefully analysed. In this paper we present a study of the co-channel interference problem, proposing a methodology to take into account the mutual interference between a LTE mobile network and a DVB-T system and highlighting the different behaviour of the two radio links.

\section{Resumen}

La creciente demanda de servicios de comunicaciones inalámbricas multimedia es un factor clave en los mercados más desarrollados. Así, las palabras de moda en las comunicaciones personales "acceso para cualquier persona, en cualquier sitio, en cualquier momento y para el servicio deseado", implican una demanda notoria y creciente del Espectro Radioeléctrico. En este sentido, la última Conferencia Mundial de Radiocomunicaciones 2007 (CMR-07) atribuyó la parte alta de la banda UHF a las redes móviles como servicio co-primario a partir del 2015 en la Región 1, aprovechando el Dividendo Digital debido a la mayor eficiencia espectral de la TV digital con respecto a la analógica. Esto tiene el potencial de causar una interferencia perjudicial entre los sistemas de televisión y los sistemas móviles y necesita ser analizado con atención. En este artículo presentamos un estudio del problema de la interferencia co-canal en dicho escenario, proponiendo una metodología para tener en cuenta la interferencia entre una red móvil LTE y un sistema televisivo DVB-T, poniendo de relieve el comportamiento diferente de los dos radioenlaces. 


\section{Introduction}

The first years of the new millennium saw two driving factors deeply influencing the spectrum management scenarios. On the one hand users already accustomed to broadband and multimedia services provided by the fixed line operators started requiring the same services while on the move, thus leading to an ever increasing market interest for wireless broadband services. On the other hand, thanks to the greater spectrum efficiency of the digital broadcast with respect to the analogue one, the television Digital Switchover process is releasing some very valuable portion of the spectrum (the so called Digital Dividend) that can be reallocated to other services. In order to exploit such an opportunity while satisfying the market requests, the last World Radiocommunication Conference (WRC 07) allocated on a co-primary basis the upper part of the UHF band (channels 61 to $69,790862 \mathrm{MHz}$ ) to mobile services (exception made for aeronautical mobile) in Region 1, including Europe, starting from June 2015, and allowed some EU countries to utilise this allocation before 2015, in a specific sub-band subject to technical coordination with other neighbouring countries (European Commission - Information Society and Media Directorate-General, Radio Spectrum Committee [DG-INFSO], 2008).

This decision gives rise to new interference issues to be coped with, due to the coexistence of digital broadcast television and mobile radio services in the same or adjacent frequency bands: (i) co-channel interference between neighbouring countries or regions, one of them using the $790862 \mathrm{MHz}$ band for mobile system and the other for broadcast television, and (ii) adjacent channel interference within a given territory, where frequencies up to $790 \mathrm{MHz}$ will be used for television broadcasting and those immediately above will be used for mobile services. In order to address these issues, the European Conference of Postal and Telecommunications Administration (CEPT) set up various study groups.

Previous works, related to the co-existence between mobile and digital broadcast television, generally focus on one system that has to be protected, thus providing the operational constraints for the other system, which is considered as interferer. Šakić, Gosta, and Grgić, S (2009); Conference Preparatory Group Project Team D [CPGPTD $]$ (2010a) provide interesting results obtained considering a UMTS mobile system interfering with a Digital Video Broadcasting-Terrestrial (DVB-T) system. On the other hand, Setiawan, Gunawan and Sirat (2009) provide an analysis of the mobile radio performance degradation as a consequence of DVB T interference.

In this paper an analysis of the co-existence of primary services is presented, focusing on the study of mutual interference between DVB T broadcasting and 3GPP Long Term Evolution (LTE) mobile systems. We propose a versatile methodology to take into 
account both the interference originated from the mobile radio systems to the broadcast system and the interference generated from the TV transmitters to the cellular system from a performance degradation point of view. The proposed methodology can be easily adapted and applied to different configurations, for protecting either DVB T or mobile services. The aim of this work is to identify the most critical radio link in terms of co-channel interference in different scenarios, and define both appropriate guard distances between the interfering systems and transmitters operational characteristics such that specific Quality of Service requirements are met. In this paper we concentrate on co channel interference issues, while the study of adjacent channel interference is left for future work.

A previous contribution by the authors can be found in Guidotti, Guiducci, Barbiroli, Carciofi, Grazioso and Riva (2011), where the number of base stations in the LTE network was assumed constant. In this paper we present an extension of the study to take into account the cumulative effect of the number of base stations, following the Italian contributions presented in CPGPTD (2010b, 2011).

In Section II we present the simulated scenario, describe the assumptions made on the two interfering systems, and on the propagation model, and depict the simulation procedure. We provide the simulation results for the considered study cases in Section III, and some concluding remarks in Section IV.

\section{Simulation scenario}

In order to shed some light on the compatibility issues between cellular and broadcast systems, we performed a simple Monte Carlo simulation (100 iterations) on the considered area, where both a DVB $\mathrm{T}$ transmitter and a cellular network are present. The DVB $\mathrm{T}$ transmitter and the mobile network serve non adjacent areas, whose reciprocal position depends on the parameter configurations considered in the different simulations.

The proposed methodology is based on the evaluation of the cumulative distribution of the Signal-to-Interference plus Noise-Ratio (SINR) and of the consequent degradation of DVB T and LTE system performance due to the mutual interference.

The analysed scenario comprises a mobile radio system and a DVB $\mathrm{T}$ transmitter. Two different aspects have been considered (Fig. 1):

» case study 1: interference generated by a certain number of base stations (BSs) versus DVB T receivers;

» case study 2: one DVB T transmitter (of height hTx) which acts as external interferer versus several LTE Base Stations (BSs).

It is worth noting that in case study 2 we decided to take into account the uplink because it is the most critical link. This may not seem obvious, but it is due to the fact that cellular base stations are considerably higher than mobile terminals, hence they can receive a larger amount of interference from the DVB-T transmitter. The 


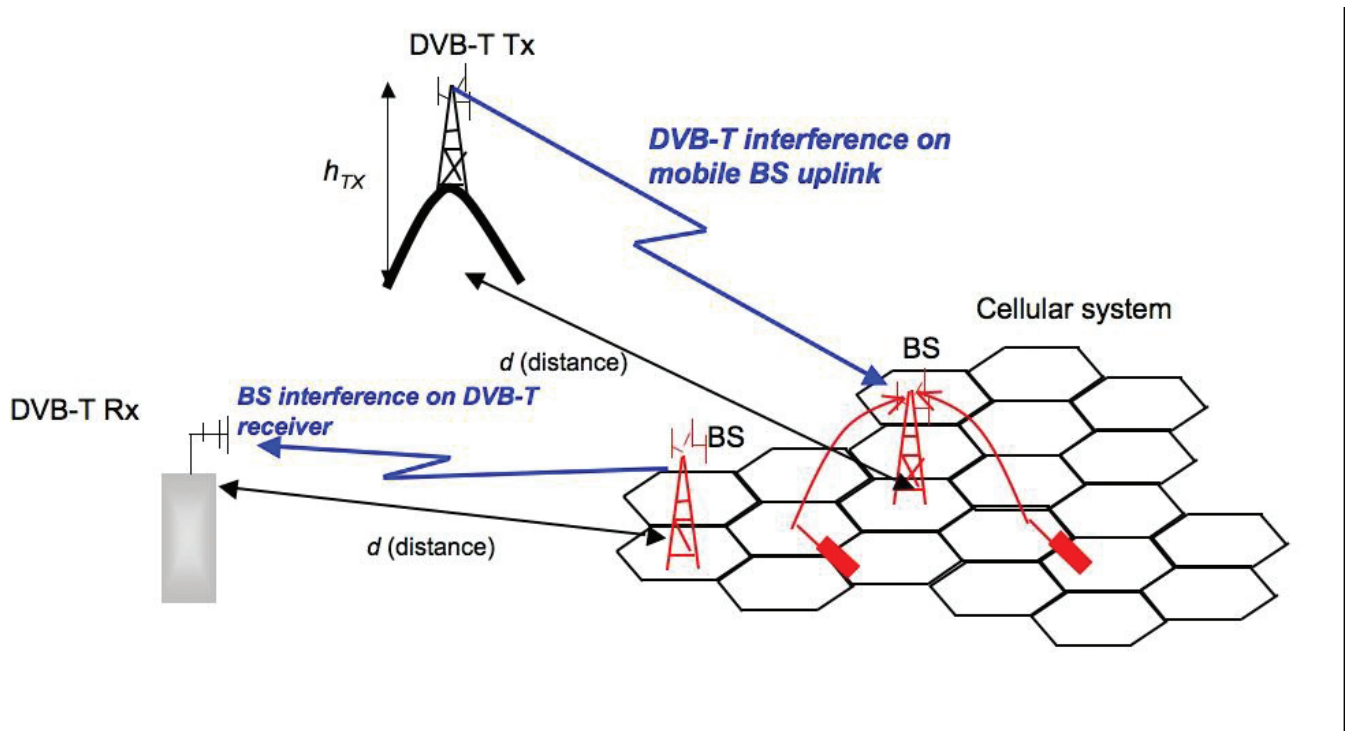

Figure 1. Simulation scenario

downlink analysis is left for further studies.

Also the interference caused by mobile terminals over the DVB T receivers will be addressed in future works, owing to the low height and transmitted power of the mobile terminals.

\section{A. Cellular layout and system parameters}

The main simulation parameters are shown in Table 1.

We assumed a channel bandwidth of $5 \mathrm{MHz}$ for LTE, as for this bandwidth the whole BS transmitted power is in the in-band transfer function of the victim DVB $\mathrm{T}$ receiver. Therefore, in case study 1 , as the power spectrum of a DVB $\mathrm{T}$ signal is approximately flat in its $8 \mathrm{MHz}$ channel, the interference generated on the $5 \mathrm{MHz}$ LTE channel can be assimilated to AWGN.

The adopted cellular layout is shown in Fig. 2. It comprises 99 base stations, but the statistics are collected only in the innermost 42 of them (enclosed in the smaller square in the figure), to avoid border effects.

We simulated the Link Adaptation behaviour of LTE mobile system as a function of the SINR, which for the purpose of this work is assumed equivalent to Signalto-Noise-Ratio (SNR), owing to the assumption that the interferer behaves like an AWGN source. Among the different modulations admitted for LTE systems we have selected those in Table 2 as representative case. The corresponding throughput values as function of SNR thresholds are taken from 3rd Generation Partnership Project [3GPP] (2008) and are expressed in bits/s/Hz. 


\begin{tabular}{cc}
\hline Cell radius & $2 \mathrm{Km}$ \\
\hline Simulation area & $900 \mathrm{Km} 2(30 \mathrm{x} 30 \mathrm{Km})$ \\
Operating frequency & $800 \mathrm{MHz}$ \\
\hline Total number of base stations (BSs) & 99 \\
Number of BSs in central area & 42 \\
Cluster size & 3 \\
\hline BS antenna height & $30 \mathrm{~m}$ \\
\hline BS Rx antenna gain & $15 \mathrm{~dB}$ \\
\hline BS transmitted power & $43 \mathrm{dBm}$ \\
\hline Number of User Equipments (UEs) generated for each & 200 \\
Monte Carlo simulation & $1.5 \mathrm{~m}$ \\
UE antenna height & $0 \mathrm{~dB}$ \\
\hline UE Tx antenna gain & $23 \mathrm{dBm}$ \\
\hline UE transmitted power & \\
\hline
\end{tabular}

Table 1. Main simulation parameters

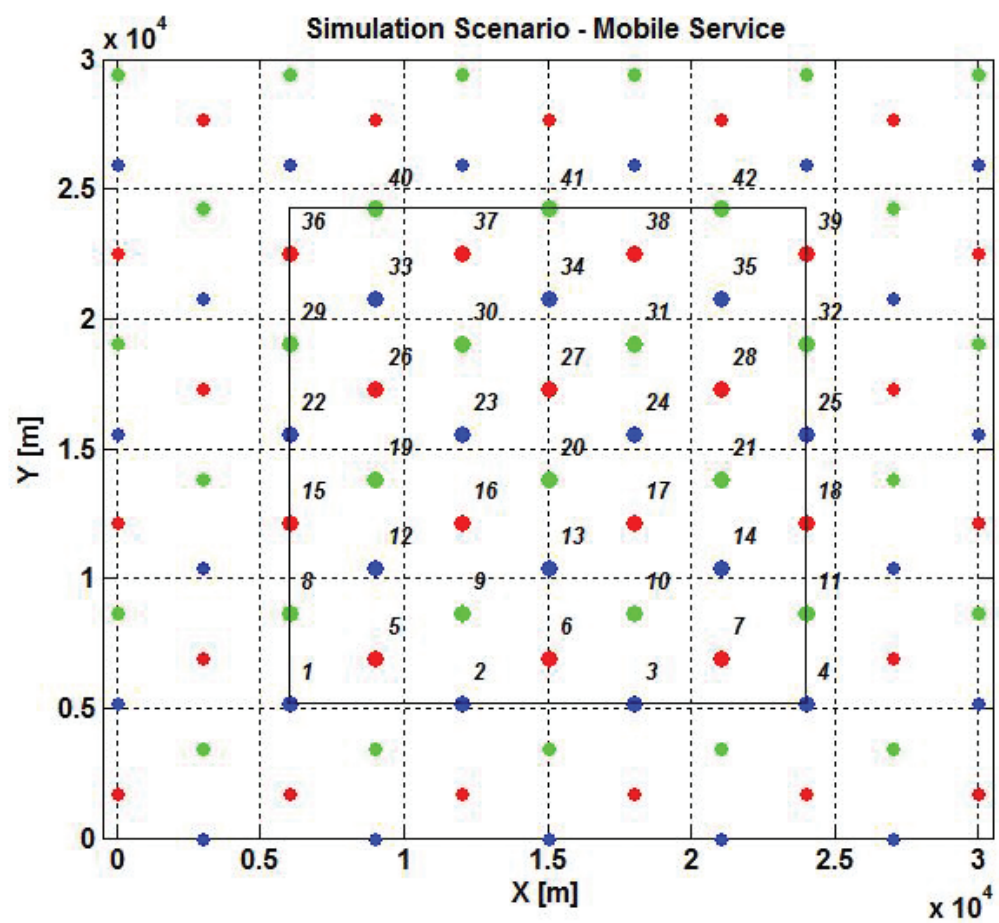

Figure 2. Cellular layout (different markers are used for different frequencies) 


\begin{tabular}{cccc} 
Modulation & Code rate & SNR $[\mathrm{dB}]$ & Rate [bit/s/Hz] \\
\hline \multirow{2}{*}{ QPSK } & $1 / 2$ & 1 & 1.0000 \\
& $2 / 3$ & 2.9 & 1.3200 \\
\hline \multirow{2}{*}{ 16-QAM } & $1 / 2$ & 6.6 & 2.0000 \\
& $2 / 3$ & 10 & 2.6200 \\
\hline \multirow{2}{*}{ 64-QAM } & $2 / 3$ & 13.8 & 4.0000 \\
\hline
\end{tabular}

Table 2. Throughput as a function of uplink snr for lte ( $5 \mathrm{mhz}$ channel)

Finally, the field strength is computed by using the Extended Okumura-Hata model (International Telecommunication Union - Radiocommunication sector, Joint Task Group 5-6 [ITU-R JTG 5-6], 2010) for the mobile radio signal assuming urban environment, while for the DVB-T interferer we used the ITU R P.1546 model (International Telecommunication Union - Radiocommunication sector [ITU-R], 2009).

\section{B. DVB-T system parameters}

The main simulation parameters are shown in Table 3.

\section{Television Tower}

ERP

Antenna height

Antenna pattern

Operating frequency

\begin{tabular}{|cc}
\hline Operating frequency & $800 \mathrm{MHz}$ \\
\hline Antenna gain & $14.15 \mathrm{dBi}$ \\
\hline Antenna height & $10 \mathrm{~m}$ \\
\hline Antenna pattern & $\begin{array}{c}\text { Mask taken from International } \\
\text { Telecommunication Union - }\end{array}$ \\
\hline Receiver minimum SNR & $\begin{array}{c}\text { Radiocommunication sector [ITU-R] (1992) } \\
\text { Noise figure }\end{array}$ \\
\hline Noise equivalent bandwidth & $7 \mathrm{~dB}$ \\
\hline $\begin{array}{c}\text { Number of TV receivers generated for } \\
\text { each Monte Carlo simulation }\end{array}$ & 200 \\
\hline
\end{tabular}

$50 \mathrm{dBm}$ or $70 \mathrm{dBm}$

$100 \mathrm{~m}$ or $200 \mathrm{~m}$

Omnidirectional in azimuth

$800 \mathrm{MHz}$

Table 3. Main simulation parameters 
Different DVB T transmitter configurations have been considered in the simulations by varying the Effective Radiated Power (ERP) and the antenna height. The cell radius varies with the configuration and it is determined according to the Reference Planning Configurations (RPCs) defined in ITU-R (2006), assuming:

- $\quad$ Location Probability (LP): 95\%

- $\quad$ Emed: $58.2 \mathrm{~dB} \mu \mathrm{V} / \mathrm{m}$ (ITU-R, 2006, Annex 3.4)

Note that in order to obtain a $95 \% \mathrm{LP}$ at the cell edge, $9.05 \mathrm{~dB}$ must be added to the receiver minimum required $\mathrm{SNR}$.

In each simulation run the TV receiver positions have been randomly generated within the DVB-T coverage area.

\section{Simulation results}

\section{A. Case study 1: mobile interferer vs victim DVB-T}

Several Monte Carlo simulations have been performed, in order to evaluate the effect of co-channel interference due to a mobile network on DVB-T receivers. For each simulation, we carried out 100 iterations with 200 different receiver positions, randomly generated within the DVB-T coverage area.

Different configurations of DVB-T transmitter height and ERP have been considered and the effect of the co-channel interference has been evaluated varying the distance between the broadcasting and mobile service areas.

Fig. 3 shows the Cumulative Distribution Functions (CDF) of the SNR and the SINR of the received DVB-T signal obtained with $\mathrm{h}_{\mathrm{Tx}}=100 \mathrm{~m}$ and $\mathrm{ERP}=50 \mathrm{dBm}$ and for various distances between the edge of the DVB-T coverage area edge and the centre of area served by the LTE network. We clearly notice the effect of the distance, with a serious interference when the distance is $30 \mathrm{Km}$. Increasing the distance causes a reduction of interference, and as expected the CDFs quickly approach the nointerference case for higher distances.

In Fig. 4 we show the equivalent CDFs for the case of $h_{T x}=200 \mathrm{~m}$ and $\mathrm{ERP}=70 \mathrm{dBm}$. As expected, owing to the higher transmitter and the increased ERP, the effect of LTE interference is less serious in this case: we observe a moderate effect for $d=30 \mathrm{Km}$ (about $2 \mathrm{~dB}$ at the $50^{\text {th }}$ percentile), while for greater distances all the CDFs collapse towards the no-interference case.

From the CDFs, we are able to compute the performance degradation in the DVB-T broadcasting service. For instance, since the required minimum SNR for the TV receiver is $21 \mathrm{~dB}$, as stated in Table III, the degradation of SNR due to the neighbouring mobile interfering system causes the reduction of the service coverage area.

This effect can be clearly seen in the following figures. Fig. 5 shows the covered (in green) and the uncovered (in red) locations by the DVB-T signal, for a transmitter 


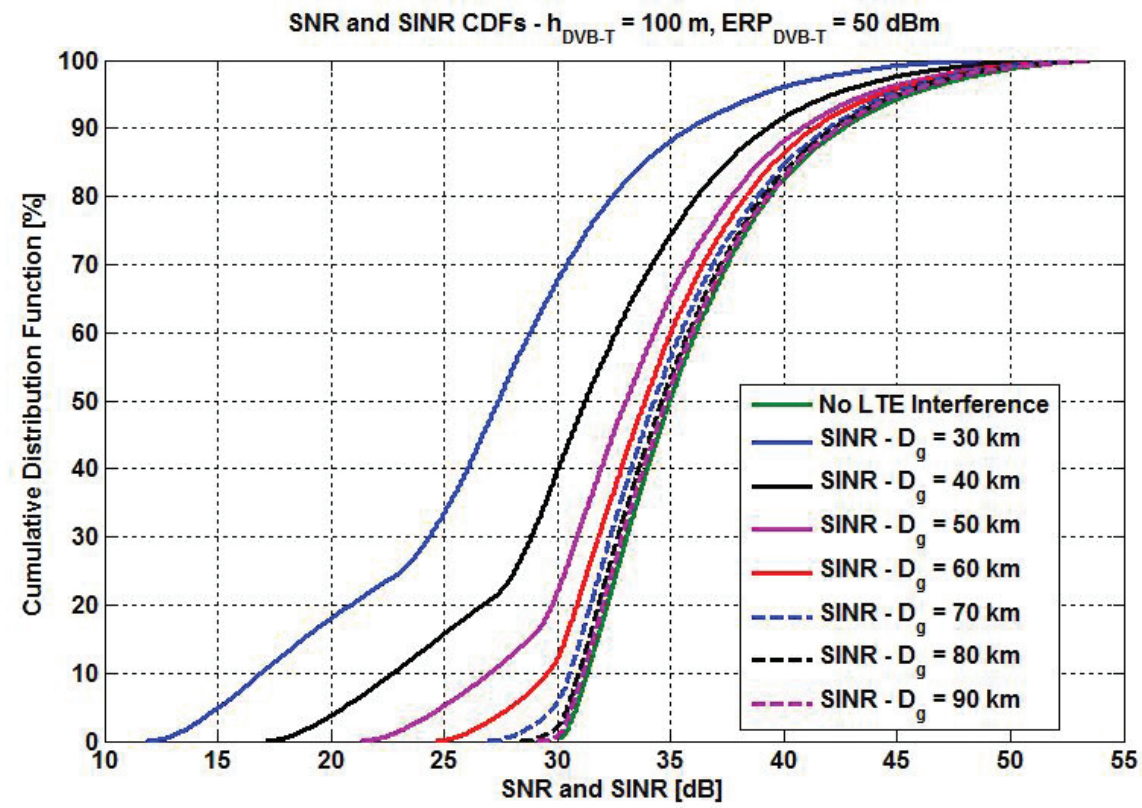

Figure 3. SNR and SINR CDF of the DVB-T received signal $(\mathrm{hTV}=100 \mathrm{~m}, \mathrm{ERP}=50 \mathrm{dBm})$

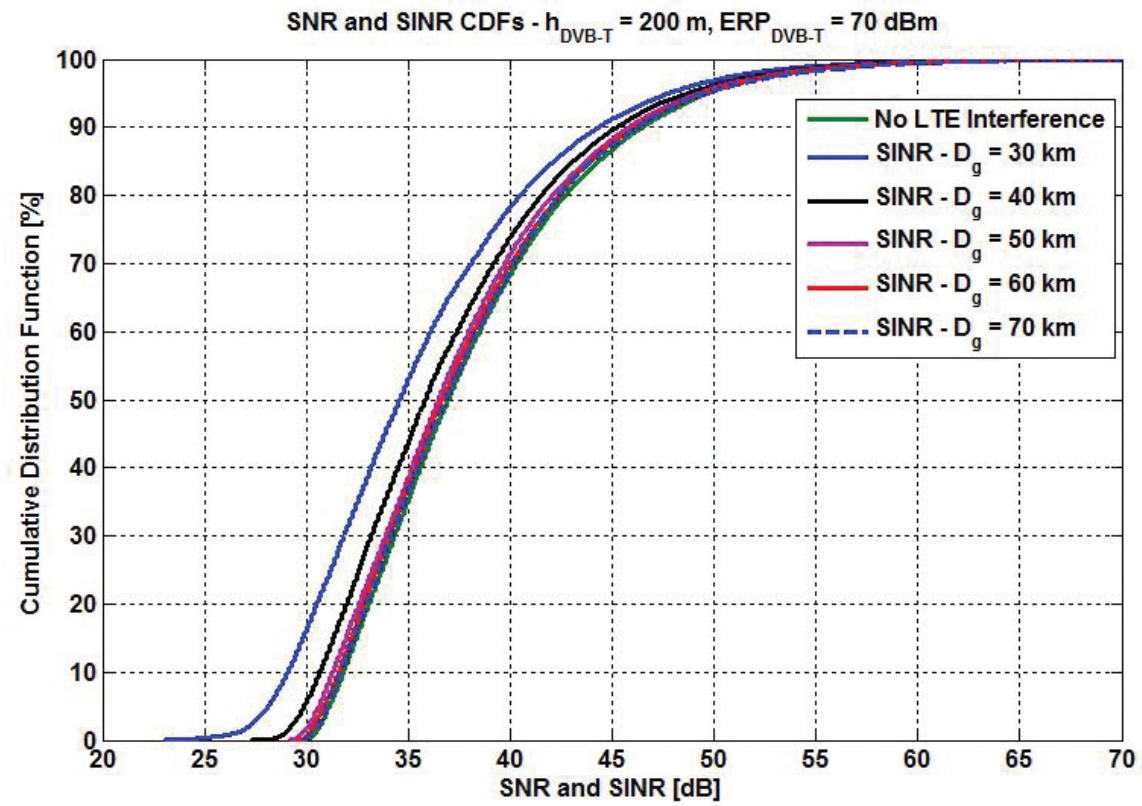

Figure 4. SNR and SINR CDF of the DVB-T received signal $(\mathrm{hTV}=200 \mathrm{~m}, \mathrm{ERP}=70 \mathrm{dBm})$ 
with $\mathrm{h}_{\mathrm{Tx}}=100 \mathrm{~m}$ and $\mathrm{ERP}=50 \mathrm{dBm}$. Obviously, the few uncovered locations are close to the coverage area limit (about $5 \mathrm{Km}$ from the transmitter). The white circle around the transmitter corresponds to distances less than $1 \mathrm{Km}$, where the propagation model is not applicable.

In the subsequent figures, we observe the effect of interference as the distance between the two networks gradually decreases from 90 to 60 and $30 \mathrm{Km}$ (Fig. 6, Fig. 7 and Fig. 8, respectively).

We notice a sharp increase of the uncovered locations when the distance decreases. The asymmetry in the interfered area is due to the antenna pattern of TV receivers.

We can also summarise the results in terms of uncovered locations percentage, are shown in Table 4. Whenever the DVB-T service degradation is lower than $1 \%$, the interfering effect of the mobile network has been considered as negligible. The corresponding configurations are highlighted in pale yellow.

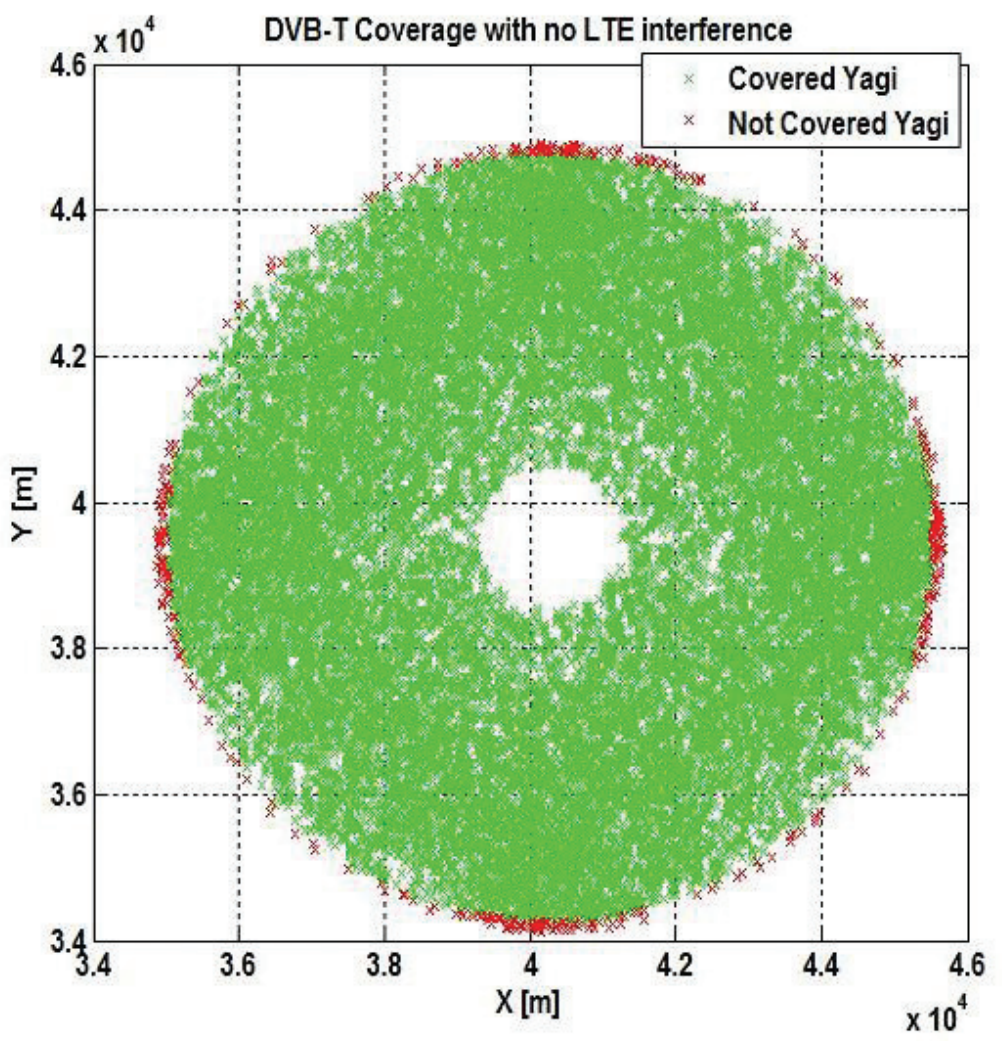

Figure 5. Covered DVB-T locations (no LTE interference) 


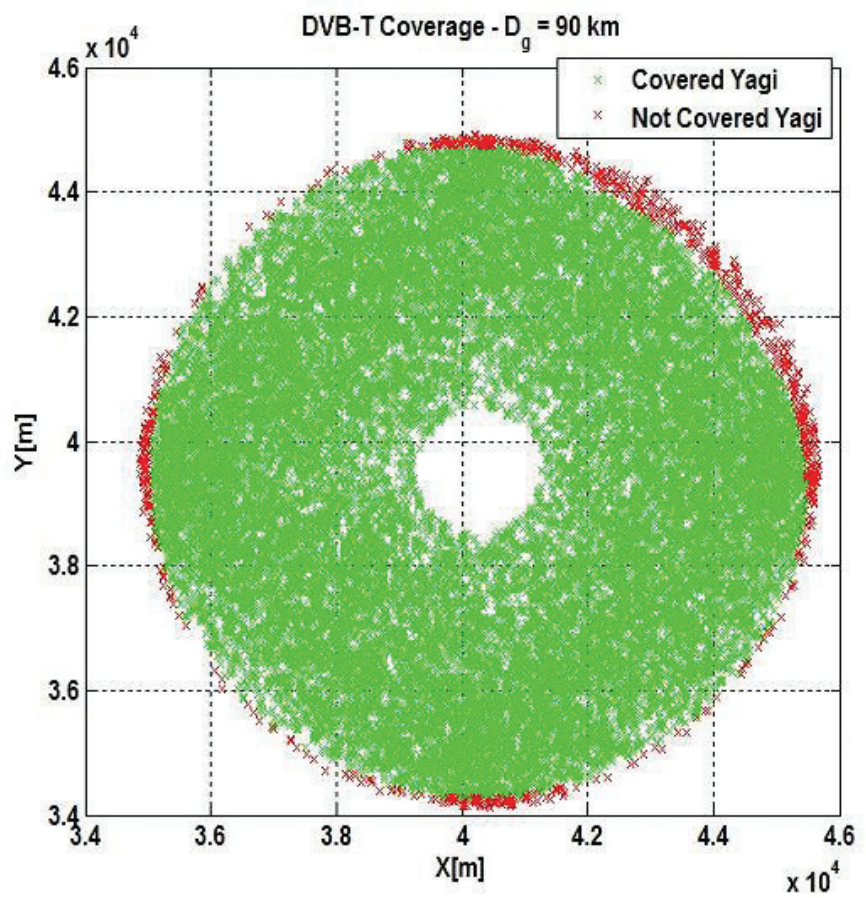

Figure 6. Covered DVB-T locations $(d=90 \mathrm{Km})$

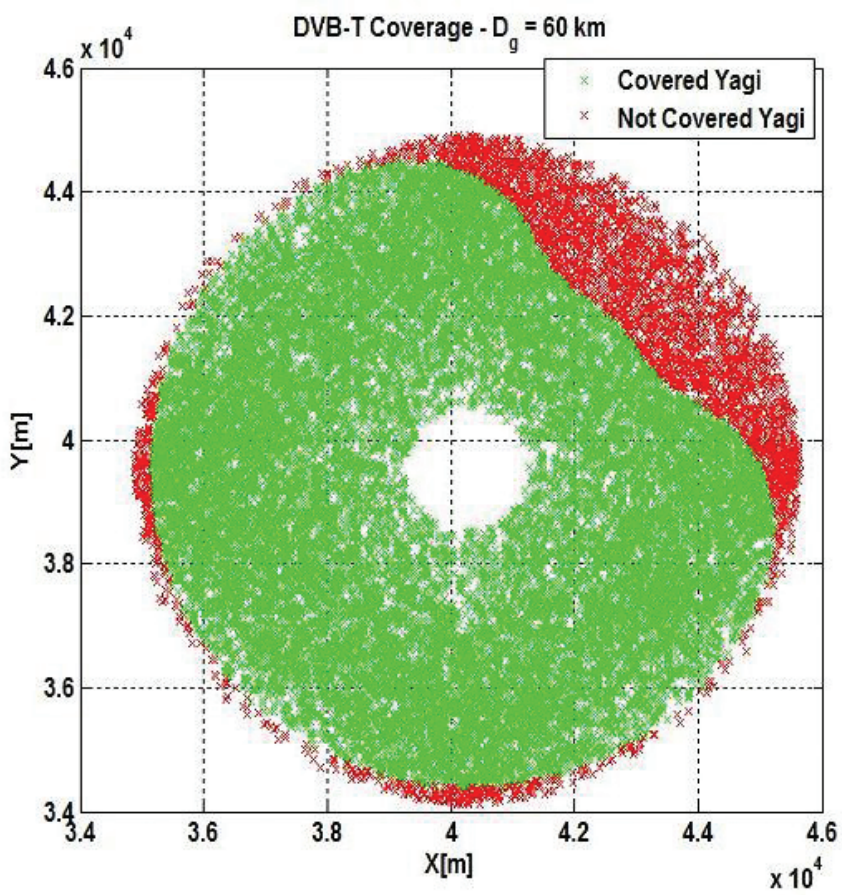

Figure 7. Covered DVB-T locations $(d=60 \mathrm{Km})$ 


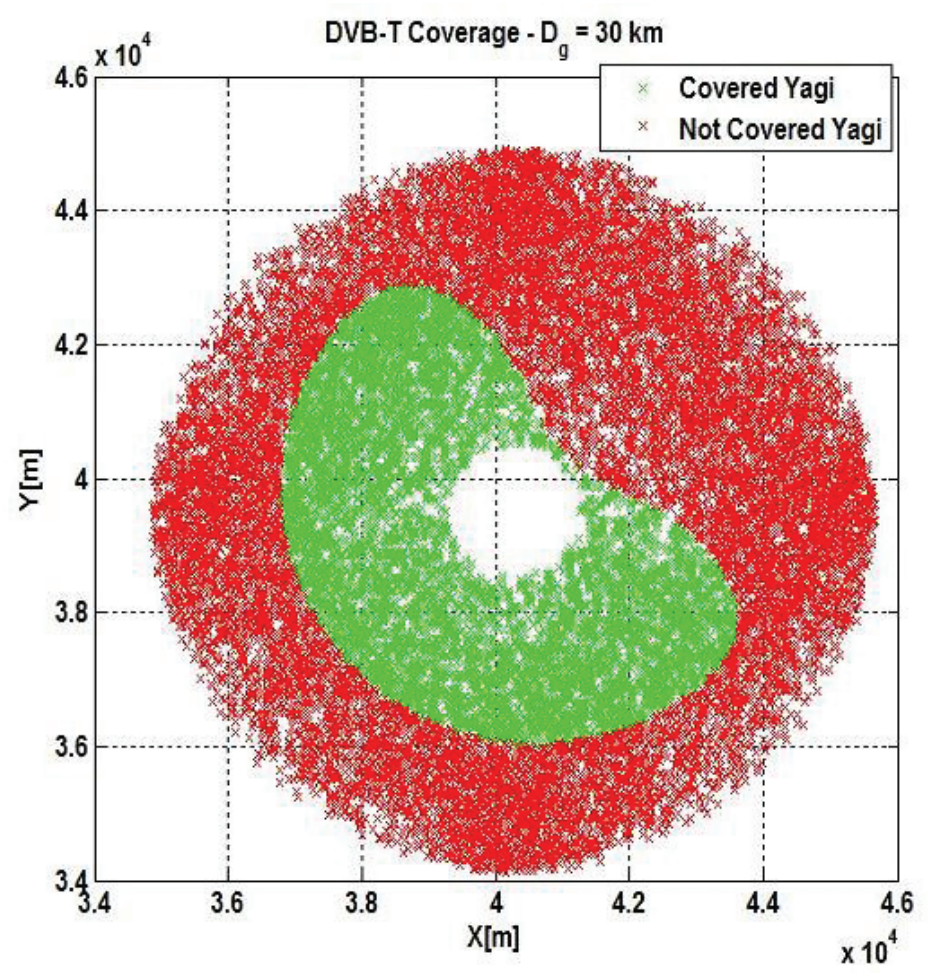

Figure 8. Covered DVB-T locations $(d=30 \mathrm{Km})$

Distance between mobile area and DVB-T coverage edge [km]

$\begin{array}{lllllllll}\text { DVB-T TX height } & \text { ERP }[\mathrm{dBm}] & 30 & 40 & 50 & 60 & 70 & 80 & 90\end{array}$

\begin{tabular}{|c|c|c|c|c|c|c|c|c|}
\hline \multirow{2}{*}{$100 \mathrm{~m}$} & 50 & 22.52 & 8.93 & 3.30 & 1.25 & 0.48 & 0.20 & 0.09 \\
\hline & 70 & 4.39 & 1.31 & 0.44 & 0.18 & 0.08 & 0.04 & 0.02 \\
\hline & & \multicolumn{7}{|c|}{$\begin{array}{l}\text { Distance between mobile area } \\
\text { and DVB-T coverage edge [km] }\end{array}$} \\
\hline
\end{tabular}

$\begin{array}{lllllllll}\text { DVB-T TX height } & \text { ERP }[\mathrm{dBm}] & 30 & 40 & 50 & 60 & 70 & 80 & 90\end{array}$

\begin{tabular}{l|ccccccccc}
\hline \multirow{2}{*}{$200 \mathrm{~m}$} & 50 & 18.73 & 7.05 & 2.57 & 0.92 & 0.35 & -- & -- \\
& 70 & 1.58 & 0.49 & 0.18 & 0.08 & 0.04 & 0.02 & 0.00 \\
\hline
\end{tabular}

Table 4. DVB-T service degradation [\%] (minimum $\mathrm{C} / \mathrm{N}=21 \mathrm{~dB}$ ) 
The minimum distance between the mobile area and the DVB-T coverage edge for which the service degradation is acceptable (that is not higher than $1 \%$ ) is referred to as guard distance. We notice how it is affected by the ERP and by the height of the transmitter.

As expected, the worst case from the DVB-T point of view corresponds to lower DVB-T transmitter ERP. Increasing the ERP from $50 \mathrm{dBm}$ to $70 \mathrm{dBm}$ results in a reduction of the guard distance up to $20 \mathrm{~km}$ for both $\mathrm{hTV}=100 \mathrm{~m}$ (from $70 \mathrm{~km}$ to $50 \mathrm{~km}$ ) and hTV=200 $\mathrm{m}$ (from $60 \mathrm{~km}$ to $40 \mathrm{~km}$ ). It can be concluded that a high power transmitter is reasonably well protected from interference generated by a mobile system, whereas a gap-filler, which has lower ERP and lower height, might need a higher degree of protection.

As anticipated in the introduction, we also studied the cumulative effect of the number of base stations on the DVB-T coverage area (see Table 5). We simulated an intermediate case between the two ERP values shown above, i.e. $60 \mathrm{dBm}$, with antenna height equal to $200 \mathrm{~m}$.

\begin{tabular}{|c|c|c|c|c|c|c|}
\hline \multirow[b]{2}{*}{ No. of BSs } & \multicolumn{6}{|c|}{ Distance between DVB-T cell edge } \\
\hline & $5 \mathrm{~km}$ & $10 \mathrm{~km}$ & $20 \mathrm{~km}$ & $30 \mathrm{~km}$ & $40 \mathrm{~km}$ & $50 \mathrm{~km}$ \\
\hline $\begin{array}{c}4 \\
(\text { Area side }=15 \mathrm{~km})\end{array}$ & 22.92 & 10.04 & 1.91 & 0.45 & 0.14 & 0.06 \\
\hline $\begin{array}{c}9 \\
(\text { Area } \operatorname{side}=20 \mathrm{~km})\end{array}$ & 37.15 & 19.92 & 4.58 & 1.11 & 0.35 & 0.12 \\
\hline $\begin{array}{c}25 \\
(\text { Area } \operatorname{side}=25 \mathrm{~km})\end{array}$ & 65.22 & 43.05 & 13.99 & 3.82 & 1.19 & 0.41 \\
\hline $\begin{array}{c}42 \\
(\text { Area side }=30 \mathrm{~km})\end{array}$ & 81.44 & 59.50 & 23.78 & 7.35 & 2.29 & 0.76 \\
\hline
\end{tabular}

Table 5. Cumulative effect of the number of LTE BSs over the DVB-T service area with $\mathrm{h}_{\mathrm{Tx}}=200 \mathrm{~m}$ and $\mathrm{ERP}=60 \mathrm{dBm}$ [uncovered locations, \%]

\section{B. Case study 2: DVB-T interferer vs victim mobile network}

In this section we analyse the effect of the DVB-T transmitter on the mobile network assuming that the two systems operate on the same channel and at a distance equal to the guard distance defined and computed in the previous sub-section. It is worth reminding that all the distances are measured between the centre of the area served by the mobile network and the DVB-T coverage edge. This approach means that first we take care of DVB-T protection, according to a certain acceptable service degradation, then evaluate the effect of the broadcasting transmitter on the mobile network. 
As recalled, in our study we have considered the effect of interference on the uplink because it is the most critical link. Evaluations are carried out through Monte Carlo simulations: we have performed 100 iterations with 200 mobile UEs, whose positions have been randomly generated.

The effect of the interferer is evaluated in terms of the percentage of mobile users that are able to access a certain modulation type, which is, of course, a function of the received SINR. The interference originated from the DVB-T transmitter has been estimated using ITU-R P.1546, considering the interference originated both at $50 \%$ and $1 \%$ of time. The DVB-T interference contribution has been added to the internal interference contribution of the LTE system considering a cluster size equal to 3 . The results are shown in Fig. 9 and Fig. 10.

Obviously worst cases are obtained for higher DVB-T transmitter ERP and antenna heights, as this causes the increase of the interferer signal strength and the reduction of the guard distance, and for a percentage of time equal to $1 \%$, as this corresponds to lower attenuation values in the ITU-R P.1546 propagation model. As a matter of facts, the performance degradation is quite evident for higher interference from the DVB-T transmitter (i.e. $\mathrm{ERP}=70 \mathrm{dBm}$ ), while with $\mathrm{ERP}=50 \mathrm{dBm}$ the impact of the DVB-T system is lower. In particular, with $\mathrm{h}_{\mathrm{Tx}}=100 \mathrm{~m}$ the performance degradation is negligible. This is due to the low interference generated on the BSs antennas with $\mathrm{ERP}=50 \mathrm{dBm}$, as in this case this value is negligible with respect to the internal interference of the mobile system (this is especially evident with the attenuation values at $50 \%$ of time).

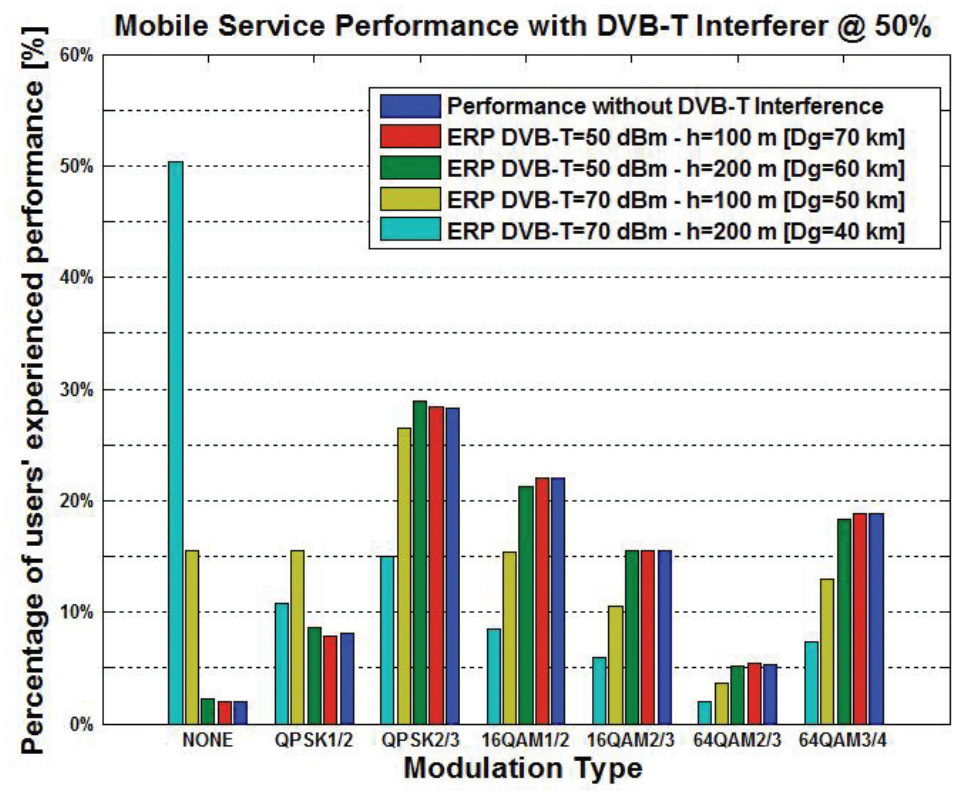

Figure 9. Mobile service evaluation for DVB-T interferer at $50 \%$ of time 


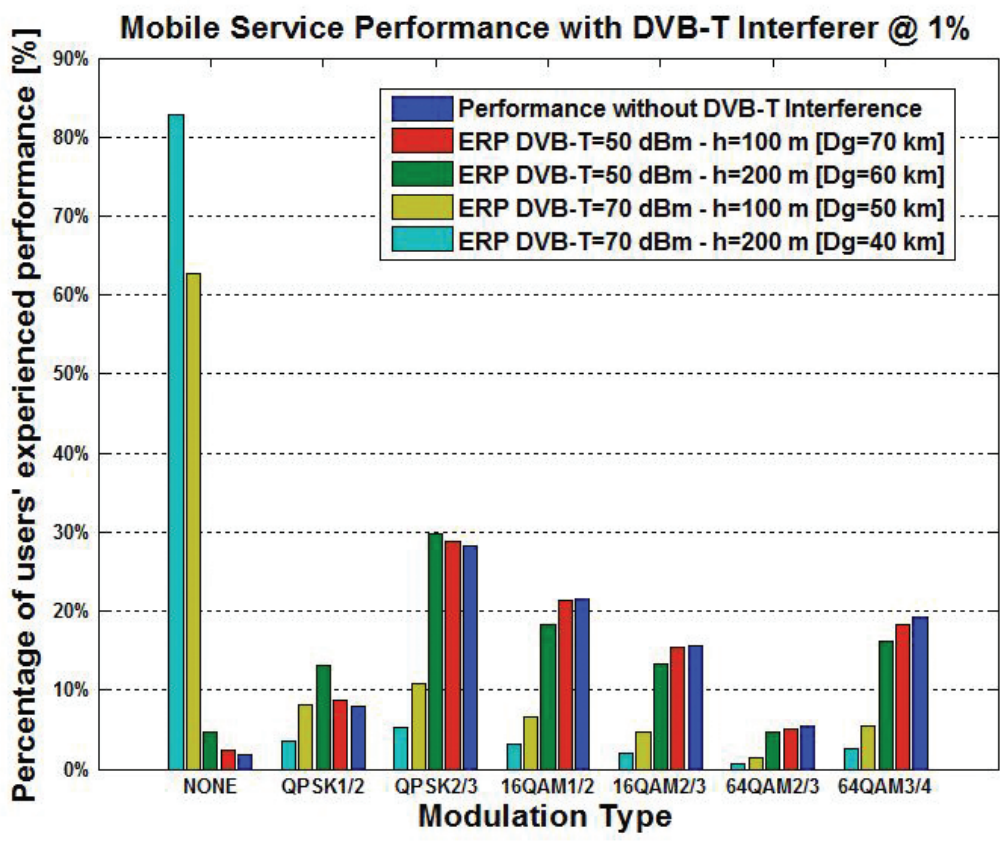

Figure 10. Mobile service evaluation for DVB-T interferer at $1 \%$ of time

A graphical representation of the locations where each modulation can be used in the central cell of the LTE network is shown in the following. Fig. 11 shows the spatial distribution of mobile terminals able to use different modulations in absence of external interference. The black dots represent uncovered locations, while other colours correspond to different modulations, and hence to different achievable throughput. Fig. 12 and Fig. 13 show the corresponding spatial distribution for the two extreme interference cases: $\mathrm{h}_{\mathrm{Tx}}=100 \mathrm{~m}, \mathrm{ERP}=50 \mathrm{dBm}$ and $\mathrm{h}_{\mathrm{Tx}}=200 \mathrm{~m}, \mathrm{ERP}=70 \mathrm{dBm}$, respectively. The distance between the two systems is the one that guarantees the DVB-T protection shown in Table IV, i.e. $70 \mathrm{Km} 40 \mathrm{Km}$ respectively.

We notice that in the first case the mobile system is only marginally affected by the DVB-T interferer, while in the second case we observe a sharp decrease of the cell coverage area, with the actual cell radius decreasing from $2 \mathrm{Km}$ to roughly $700 \mathrm{~m}$, and with the highest bit rates that can be achieved only in the immediate proximity of the base station.

As previously stated, the performance analysis of the mobile network we have just provided is based on the assumption that the two interfering systems are deployed in such a configuration that the coverage reduction of the DVB-T service is below $1 \%$.

However, there might be situations, where more interest is focused on the protection of the mobile service: which parameters should be chosen for a DVB-T system that is going to be deployed in a neighbouring area, in order to preserve an acceptable mobile service performance? 


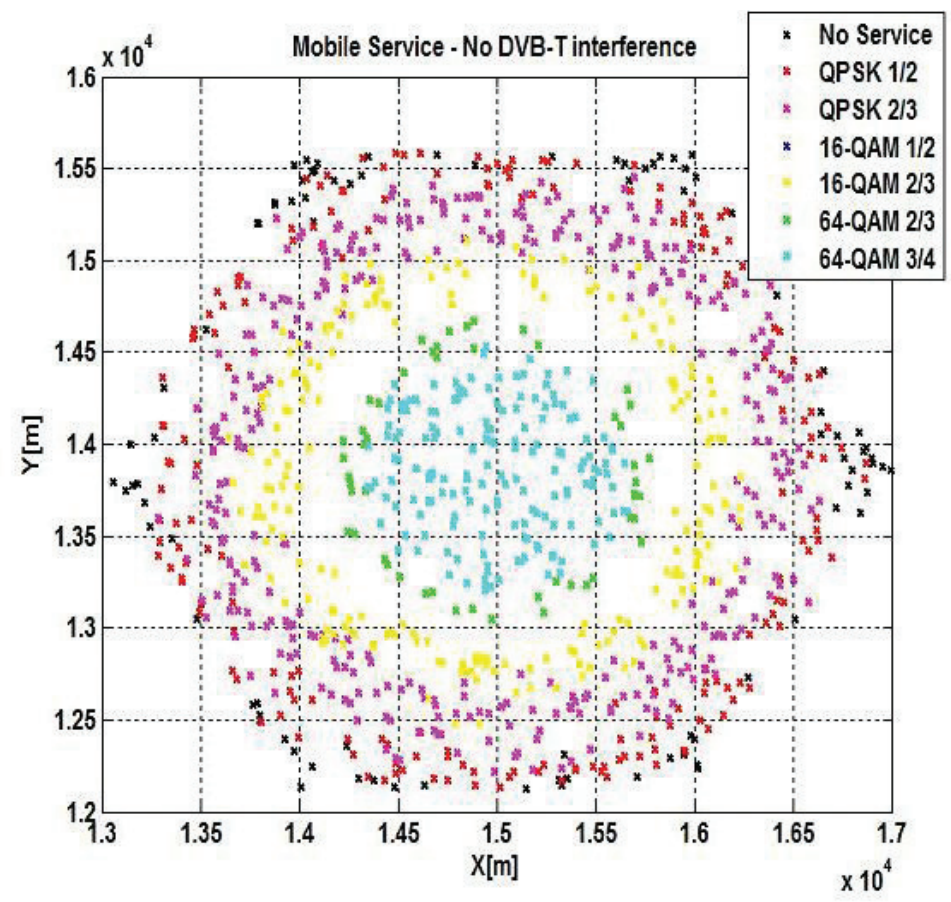

Figure 11. Mobile service and modulations without DVB-T interference

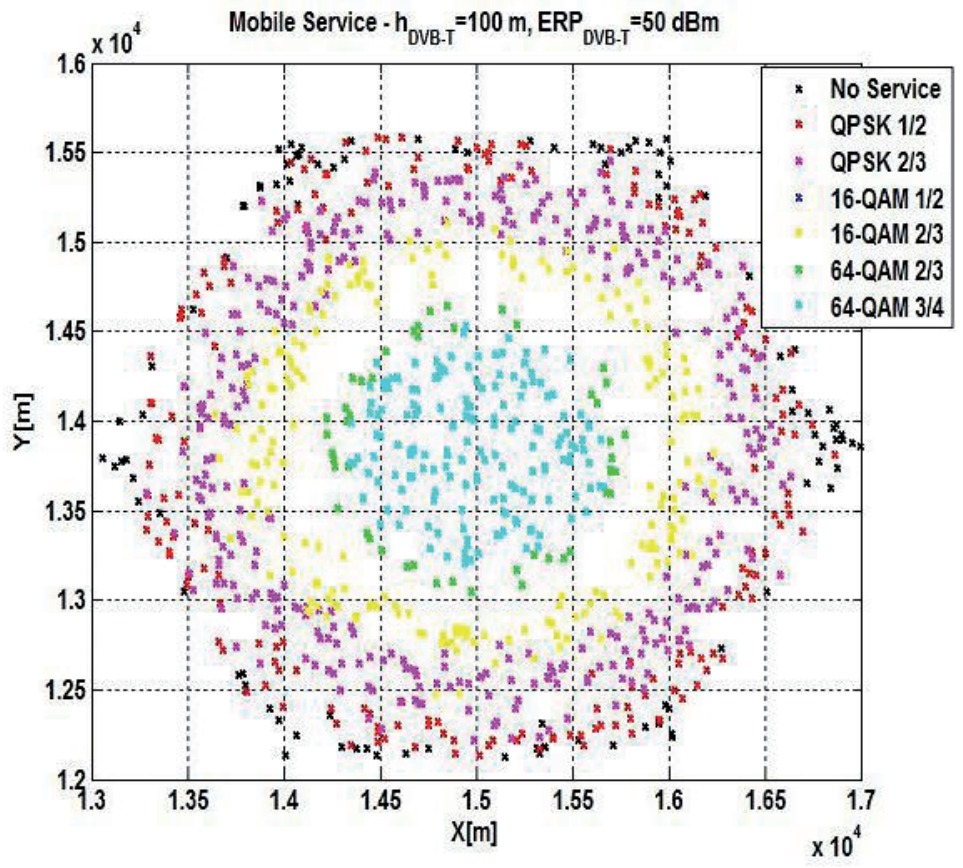

Figure 12. Mobile service and modulations with DVB-T interference $\left(\mathrm{h}_{\mathrm{Tx}}=100 \mathrm{~m}\right.$, $\mathrm{ERP}=50 \mathrm{dBm}$ ) 


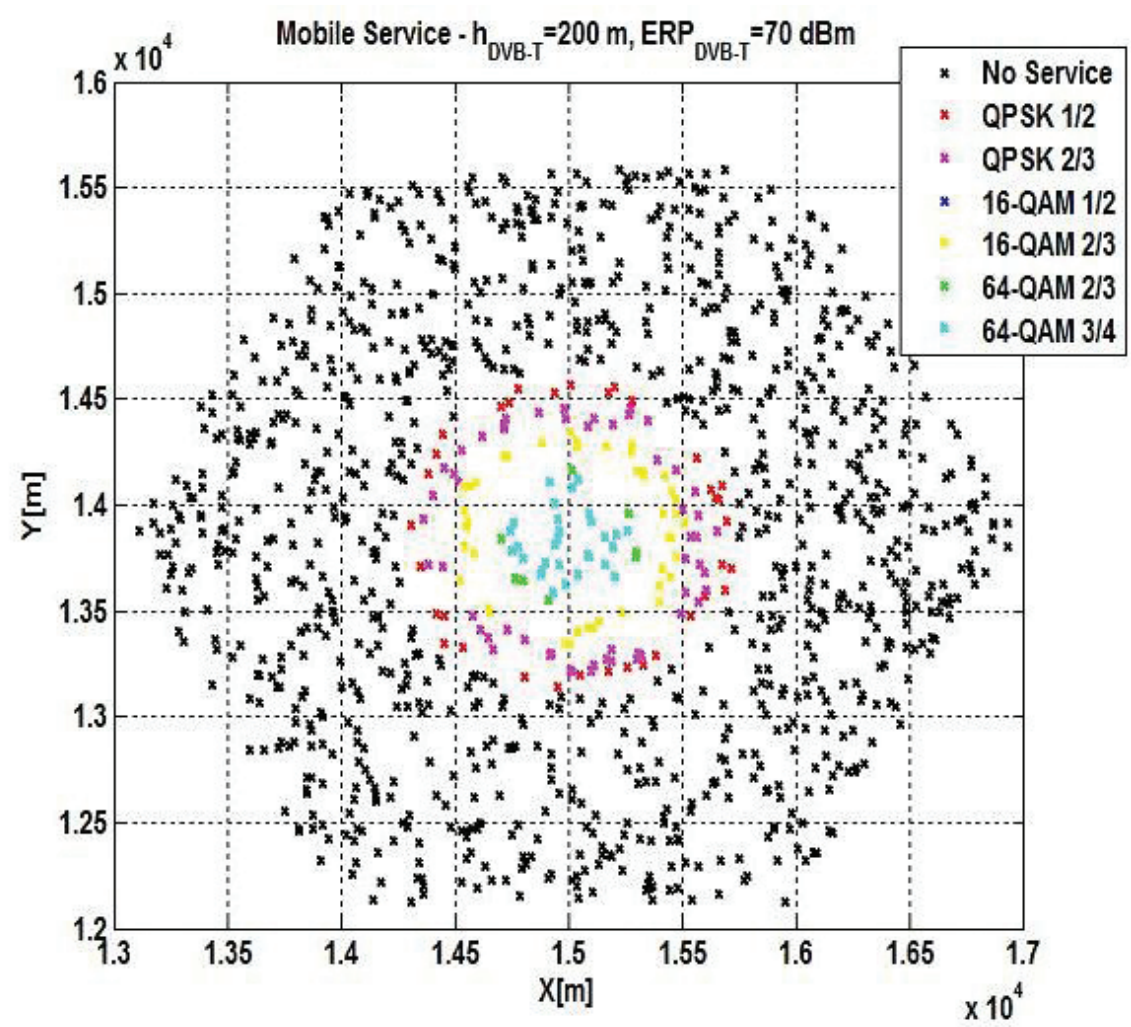

Figure 13. Mobile service and modulations with DVB-T interference $\left(\mathrm{h}_{\mathrm{Tx}}=200 \mathrm{~m}\right.$, $\mathrm{ERP}=70 \mathrm{dBm})$

We are not going to thoroughly investigate this issue. However, a good starting point for such an analysis could be the evaluation of the throughput reduction perceived by users. With this intent, in the following figures (from Fig. 14 to Fig. 17) we show the average throughput per channel and the average throughput per BS, which is the average throughput that a BS can provide to its served users. The values of distance reported in these figures are computed between the centre of the area served by the mobile network and the DVB-T transmitter, as we are not interested in the DVB-T coverage edge anymore.

Having defined the maximum acceptable throughput reduction (e.g. a degradation of $10 \%$ or $15 \%$ with respect to the throughput without co-channel interference), the DVB-T system parameters that guarantee the protection of the mobile service can be easily identified. For instance, from Fig. 17 it can be derived that if the accepted minimum throughput per channel is not lower than $10 \mathrm{Mbps}$, with a DVB-T transmitter set at $200 \mathrm{~m}$ the DVB-T ERP shall not exceed $40 \mathrm{dBm}$. 


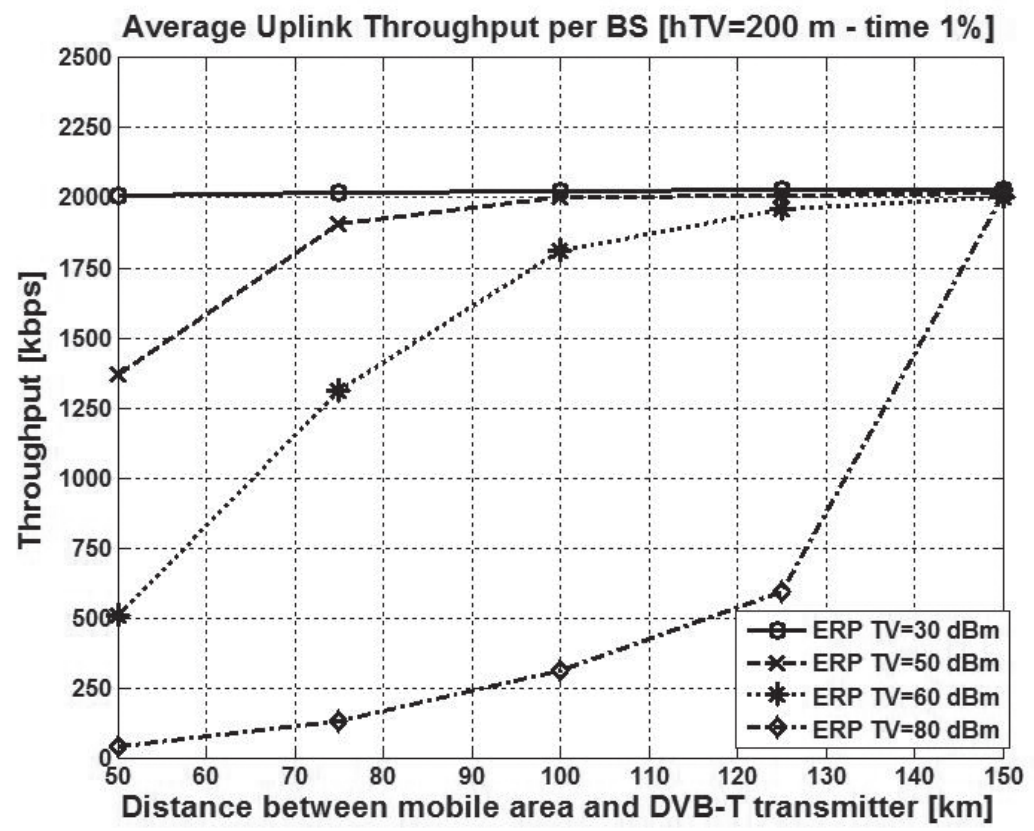

Figure 14. Average throughput per BS as a function of distance with hTV=200 $\mathrm{m}$ and interferer at $1 \%$ of time.

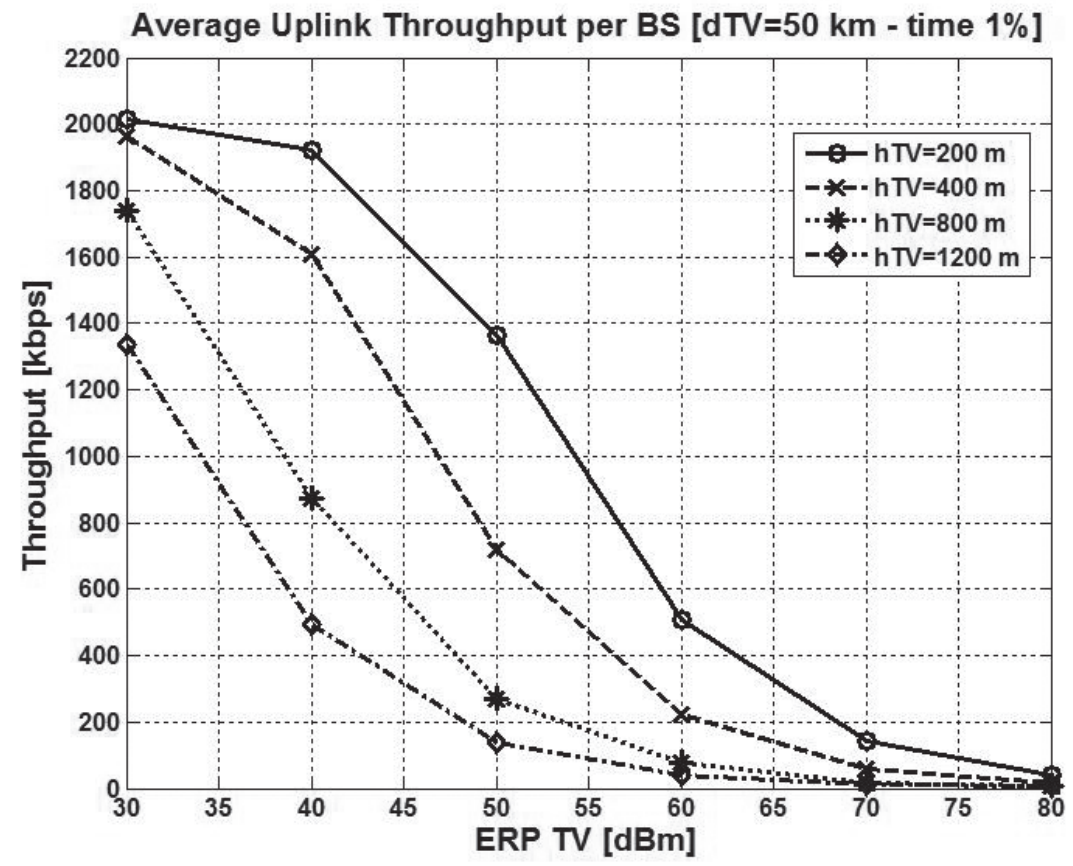

Figure 15. Average throughput per BS as a function of DVB-T ERP with dTV=50 km and interferer at $1 \%$ of time. 


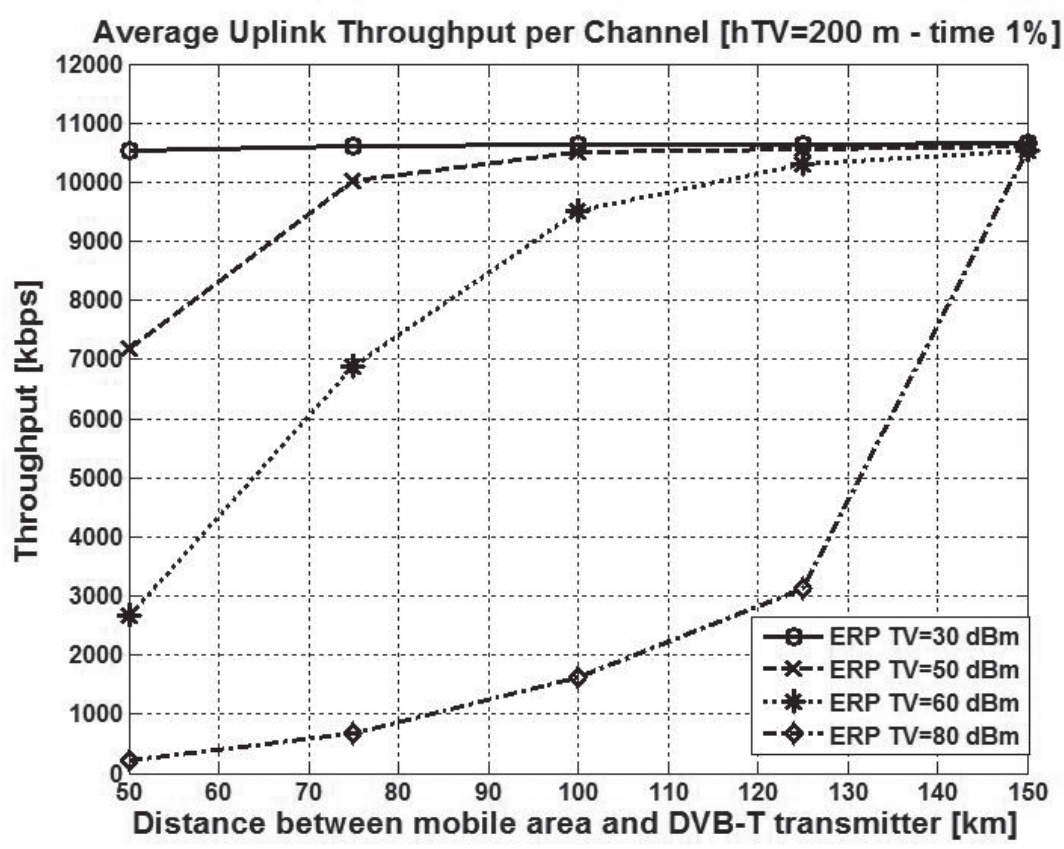

Figure 16. Average throughput per channel as a function of distance with hTV=200 m and interferer at $1 \%$ of time.

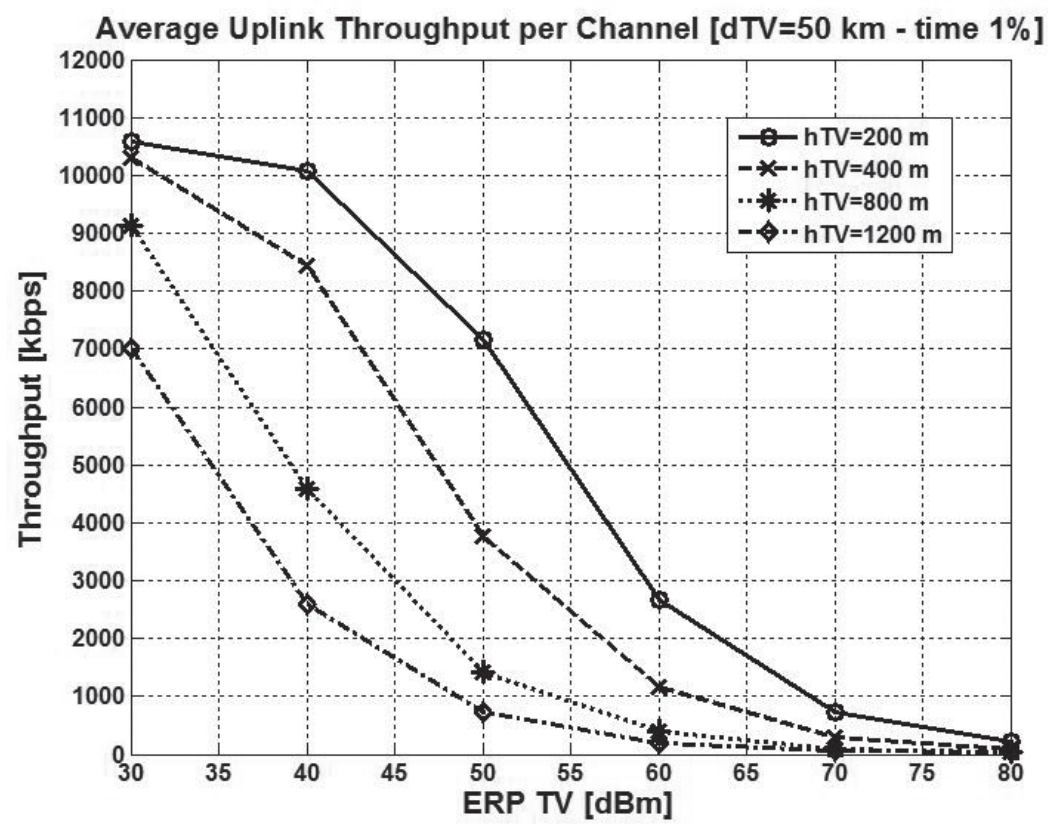

Figure 17. Average throughput per channel as a function of DVB-T ERP with dTV=50 $\mathrm{km}$ and interferer at $1 \%$ of time. 


\section{Conclusions and further work}

In this document we have proposed a theoretical analysis of mutual co-channel interference between DVB-T and mobile radio. The proposed methodology takes into account both the interference originated from the mobile radio network on the broadcasting system and the interference generated from the TV transmitter on the cellular system. The aim is to assess the reciprocal interference in order to compare the different behaviours of the two radio links, thus identifying the most critical situations. The document proposes a versatile methodology, which can be easily adapted to different configurations, for protecting either DVB-T or mobile service.

So far we concentrated on the uplink; future work may include the downlink as well, although it is expected to be less critical. In future work we will consider a more realistic propagation scenario, possibly including terrain height and land usage databases. It could be possible also to use measured values of real DVB-T networks to evaluate interference.

Another item of future investigation deals with adjacent channel interference between mobile radio and digital television operating in adjacent frequency bands.. $\boldsymbol{s T}^{\mathrm{T}}$

\section{References}

Conference Preparatory Group Project Team D [CPGPTD] (2010a). WRC12 AI 1.17 - Broadcasting vs mobile : cumulative effect of the base station (theoretical analysis) [Source: France, Doc.CPGPTD (10)036] (meeting documents $8^{\text {th }}$ CPG-PTD, Budapest, Hungary, 13-16 April 2010). Retrieved from www.ero.dk

Conference Preparatory Group Project Team D [CPGPTD] (2010b). WRC-12 A.I. 1.17 options of Method A1 [Source: Italy, Doc.CPGPTD (10)156, meeting documents $10^{\text {th }}$ CPG-PTD, Lisbon, Portugal, 14-17 December 2010). Retrieved from www.ero.dk

Conference Preparatory Group Project Team D [CPGPTD] (2011). WRC-
12 A.I. 1.17 options of Method A1, [Doc.CPGPTD (10)156] (meeting documents $11^{\text {th }}$ CPG-PTD, Paris, France, 26-29 April 2011). Retrieved from www.ero.dk

European Commission - Information Society and Media DirectorateGeneral, Radio Spectrum Committee [DG-INFSO] (2008). Opinion of the RSC pursuant to Article 4.2 of Radio Spectrum Decision 676/2002/EC [RSCOM08-06final]. Retrieved from http://ec.europa.eu/information_ society/policy/ecomm/radio_ spectrum/_document_storage/rsc/ rsc23_public_docs/rscom08-06.pdf

European Telecommunications Standards Institute - 3rd Generation Partnership 
Project (3GPP). (2009). LTE; Evolved Universal Terrestrial Radio Access (E-UTRA); Radio Frequency (RF) system scenarios (3GPP TR $36.942 \quad$ V8.1.0 Release 8; ETSI TR 136942 V8.1.0). Sophia Antipolis, France: ETSI. http://www.etsi.org/deliver/etsi_tr/1 36900_136999/136942/08.01.00_60/ tr_136942v080100p.pdf

Guidotti, A., Grazioso, P., Barbiroli, M., Carciofi, C., Guiducci, D., \& Riva, G. (2011). Coexistence and mutual interference between mobile and broadcasting systems. Proceedings. 2011 IEEE 73rd Vehicular Technology Conference, Budapest, Hungary, 1518 May 2011, pp.1-5. doi:10.1109/ VETECS.2011.5956540

International Telecommunication Union - Radiocommunication sector, Joint Task Group 5-6 [ITU-R JTG 5-6] (2010). Studies on the use of the band 790-862 MHz by mobile applications and by primary services. Retrieved from http://www.itu.int/md/meetingdoc. asp?lang $=$ en\&parent $=$ R07-JTG5.6C\&source $=$ Russian $\% 20$ Federation

International Telecommunication Union Radiocommunication sector [ITU-R] (2006). Final Acts of the Regional Radiocommunication Conference 2006 (RRC-06). Geneva, Switzerland: ITU.
International Telecommunication Union - Radiocommunication Sector (1992). Directivity and polarization discrimination of antennas in the reception of television broadcasting (Rec. ITU-R BT.419-3). Retrieved from http://www.itu.int/ dms_pubrec/itu-r/rec/bt/R-RECBT.419-3-199006-I!!PDF-E.pdf

International Telecommunication Union - Radiocommunication Sector [ITU-R] (2009). Method for point-toarea predictions for terrestrial services in the frequency range $30 \mathrm{MHz}$ to 3000 MHz (Rec. ITU-R P.1546-4). Retrieved from http://www.itu.int/dms_pubrec/ itu-r/rec/p/R-REC-P.1546-4-200910I!!PDF-E.pdf

Sakic, K., Gosta, M., \& Grgic, S. (2009). Cross-border interference between broadcasting and mobile services. Proceedings. 51 st International Symposium ELMAR-2009, 28-30 September 2009, Zadar, Croatia (pp. 229-232).

Setiawan, D., Gunawan, D., \& Sirat, D. (2009). Interference Analysis of Guard Band and Geographical Separation between DVB-T andE-UTRA in Digital Dividend UHF Band. Proceedings. ICICI-BME 2009. Bandung, Indonesia, November 23-25, 2009. doi:10.1109/ ICICI-BME.2009.5417258. 


\section{Currículum vitae}

\section{Alessandro Guidotti}

He was born in Popoli on December 14th 1983, obtained in October 2008 the Master Degree in Telecommunications Engineering (magna cum laude) from the University of Bologna.

Since January 2009, he is a Ph.D. student at the University of Bologna with funds from Fondazione Ugo Bordoni. His research interests are in the vast field of spectrum management and cognitive radios. During the Ph.D. activity, he spent 6 months at SUPELEC (Paris) as visitor researcher, working on statistical characterization of interference using stochastic geometry techniques. He represented Italy in CEPT SE43 meetings and is TPC member and reviewer for major conferences and journals.

\section{Paolo Grazioso}

Born in Bologna on June 17th, 1963, received the Electronics Engineering degree magna cum laude from the University of Bologna in February 1989. After a one-year scholarship, in 1990 he was employed by Fondazione Ugo Bordoni where he still works. His research interests span several fields of radio communications, including propagation, mobile radio system architecture, digital television, spectrum efficiency and frequency management. He participated in various international research initiatives, represented Italy in various CEPT study groups, was part of the Italian delegation at major ITU conferences (RRC-06 and WRC-07) and co-authored 50 scientific and technical papers.

\section{Marina Barbiroli}

She received her Laurea degree in Electronic Engineering from the University of Bologna in 1995. In January 2000 she received the PhD degree in Computer Science and Electronic

Engineering from the University of Bologna and since July 2001 she is a researcher at

Bologna University. Since 1999 she held several courses at Bologna University related to propagation mechanisms of the electromagnetic field. Currently she gives courses on "Electromagnetic Compatibility" and on "Electromagnetic Technologies for link design" for the second level degree in Telecommunications. Her research interests are on propagation models and planning strategies for wireless systems, including investigation of exposure levels and study of the coexistence of different systems (e.g. broadcast and mobile communications systems) operating in the same band or in adjacent bands.

\section{Claudia Carciofi}

She received the degree in Electronics Engineering from the University of Bologna in 1990. After a one research grant on ATM, in 1992 she joined Fondazione Ugo Bordoni where she was involved in the second phase of the RACE programme. In 1997 she received the $\mathrm{PhD}$ in telecommunications from the University of Bologna and joined again Fondazione Ugo Bordoni to conduct research on propagation models for coverage prediction and exposure evaluation of radio systems. Her current research activities mainly focus on flexible spectrum management strategies such as cognitive radio systems and the coexistence of different systems in the same band. She is also involved in the activity to support the Italian Minister of Economic Development for the transition process from analogue to digital television systems. 


\section{Doriana Guiducci}

She was born in Bologna, Italy. She received the Laurea degree in telecommunications engineering, in 1999, and the Ph.D. degree in computer science and electronics engineering, in 2003, both from the University of Bologna. In 2003, she joined Fondazione Ugo Bordoni (FUB), Villa Griffone, Italy, where she is currently a researcher. Her activity is on the Italian transition from analogue to digital television, with special reference to cross-border coordination matters. She also works on protection from risks due to electromagnetic fields exposure. Her research interests include mobile communications and NGN and development of efficient policies for radio spectrum management.

\section{Guido Riva}

He received the Laurea degree in Electronic Engineering in 1981 and in Physics in 1991, both from University of Bologna, Italy. Since 1985 he is with Fondazione Ugo Bordoni, mainly involved in Radio Systems Area activities. His main interests are on radio spectrum optimization, mobile radio systems and radio aspects of transition from analogue to digital television. For ten years, till 2003, he was Assistant Professor at University of Bologna, faculty of Electronic Engineering in Cesena. He is now involved in national programs about 900-MHz GSM band refarming with italian PTT ministry and about mobile QoS with AgCom, the National Authority. 